\title{
Corporate Leadership and Mass Atrocity
}

\author{
Sarah Federman $^{1}$
}

Received: 14 August 2019 / Accepted: 8 April 2020 / Published online: 15 April 2020

(c) The Author(s) 2020

\begin{abstract}
With the last Holocaust survivors quietly passing away, one might also expect to see accountability debates slowing to a trickle. Surprisingly, however, recent years show an upswing in corporate World War II-related atonement debates. Interest in corporate participation in mass atrocity has expanded worldwide; yet what constitutes ethical corporate behavior during and after war remains understudied. This article considers these questions through a study of the French National Railways' (SNCF) roles during the German occupation and its more recent struggle to make amends. This study demonstrates that ethical business leadership requires taking responsibility for past as well as current decisions. Most executives grappling with complex corporate histories work in isolation, in part because the scholarship on business ethics fails to provide guidance. Without such guidance, corporations often respond to accusations about their pasts with carefully crafted statements and legal strategies rather than deep expressions of moral leadership. To assist in remedying this tendency, this paper simultaneously encourages companies to engage in deeper reflection on corporate history, while urging scholars to help guide corporations through critical ethical conversations.
\end{abstract}

Keywords Ethical leadership $\cdot$ Holocaust $\cdot$ Corporate accountability $\cdot$ Corporate responsibility $\cdot$ France $\cdot$ SNCF $\cdot$ Railways

\section{Corporate Moral Responsibility, Past and Present}

In July 2019, the Shoah memorial in Paris hosted a namesreading ceremony for Convoy 77 , the last deportation train that left Paris for Auschwitz. This convoy departed two months after the allies arrived at Normandy. The few survivors in attendance remarked at the thinning crowd and spoke of friends recently passed and those simply too ill or frail to keep attending. ${ }^{1}$

With the diminished physical and moral presence of survivors, one might expect to see a similar decline in atonement and accountability discussions for World War II activities. To the contrary, however, recent years show an upswing in these conversations, especially regarding corporations. In March 2019, for example, the German Reimann family announced its plans to donate roughly $€ 10$ million to help atone for their ancestors' use of slave labor during World War II and for the family's support (political and financial) of Hitler and his anti-Semitic policies (Isidore 2019). While

Sarah Federman

sfederman@ubalt.edu

1 University of Baltimore, Baltimore, USA the Reimann family and JAB Holdings might not be household names, many recognize their brands: Dr. Pepper, Krispy Kreme Donuts, Panera Bread, Peets Coffee, Pret A Manger, Einstein's Bagels, and Coty. In recent years, survivors and their descendants also called upon the French, Dutch, and Hungarian National Railway companies to compensate for their predecessors' participation in the Holocaust (Karasz 2019). These debates extend beyond Europe: In October 2019, a South Korean court asked Nippon Steel \& Sumitomo Metal to pay damages for slave labor used during the war (Sang-Hun and Gladstone 2018).

Some corporations that claim to have atoned for their wartime activities continue to participate in hauntingly similar abuses. Victims of slave labor during World War II, for example, learned through an August 2019 New York Times opinion piece that Volkswagen and Siemens Corporation are profiting from China's notorious "Open Air Prison" or "re-education camps" targeting the Uyghur minority (Haas 2019). Many of the banks that supported the Nazi regime and that supposedly atoned for doing so continue to make headlines for on-going indictments. Such examples raise questions about the ability of current atonement

\footnotetext{
${ }^{1}$ Mémorial de la Shoah, "La lecture des noms des déportés du convoi 77" Paris, France, July 31, 2019.
} 
mechanisms, namely compensation and apologies, to shift corporate ethos enough to prevent future violations.

Corporations can do better. However, scholarship concerned with ethical leadership provides little guidance for those business executives willing to engage beyond carefully crafted public statements and legal strategies. This article aims to provide some guidance, first by arguing that ethical corporate leadership requires taking responsibility both for present-day business activities and the decisions of predecessors. Through this more timeless conception of moral responsibility, past harms can be addressed and current or future violations can be interrupted.

To make this argument, this article uses the recent atonement debates concerning the French National Railways' (SNCF) role in the Holocaust. Focusing on a World War II-complicit corporation makes sense given that the notion of corporate liability for participation in war crimes began in the aftermath of this conflict, albeit on a relatively shaky footing. The Trials of War Criminals before the Nuremberg Military Tribunals of 1946-1949 held roughly a dozen corporate directors accountable for their companies' wartime activities (Ferencz and Taylor 2002). Executives from I.G Farben, Flick, and Krupp, among others, received prison sentences, though none served more than eight years before heading off to run post-war Europe in various capacities. Legal lacunae and lack of public, political, and corporate will limited the scope of these trials. For example, Moore (2018), responsible for collecting and reviewing documents for the I.G. Farben case, found her work thwarted by the chief I.G. Farben archivist who claimed ignorance regarding the organization of his hundreds of shelves of neatly organized documents. When Moore sought the help of the American army general in charge of the Farben complex, he refused on account that he disagreed with the trials, especially the prosecution of industrialists.

Corporate entities never faced trial because U.S. prosecutors, as well as some French and British prosecutors, agreed to focus on individual executives. This left the question of how to handle collective accountability unresolved (Bush 2009). In spite of these limitations, the precedents set at the Nuremberg WWII military tribunals enabled plaintiffs to use the U.S. Alien Tort Statute (ATS) to hold corporations accountable for human rights abuses committed abroad (Skinner 2008). Even though the 2013 Supreme Court decision in Kiobel v. Royal Dutch Petroleum Co. limited the use of the ATS for future cases, the Nuremberg precedents made their contribution. The cultural mores that Nuremberg helped establish continue to matter, especially with so few legal mechanisms able to hold transnational actors accountable (Kelly 2016). The International Criminal Court can only try individuals not entities. The International Court of Justice only considers conflicts between states. Many smaller countries lack either the strength or judicial will to hold corporate actors accountable. Even when courts successfully hold corporations liable for human rights violations, the checks issued to victims can become simply the cost of business, rather than symbolizing a recognition of moral wrongdoing or, more substantively, providing a disincentive to continuing immoral practices.

Where law cannot reach judicially or morally, human rights-related bodies step in. Discourses about universal obligations to protect human rights proliferated after World War II, giving birth to the United Nations, the Universal Declaration of Human Rights, and the Genocide Convention. The United Nations Guiding Principles, supported by NGOs and UN Human Rights Council members, includes a section on business and human rights. Only recently did human rights advocates consider corporations as important protectors or violators of human rights (Muchlinski 2001). The UN Global Compact encourages businesses to voluntarily comply with human rights standards. Only in 2011, however, did the UN's Human Rights Council endorse this Compact and the related Guiding Principles on Human Rights developed by John Ruggie. Now, the movement has momentum: in 2019, the Human Rights Council drew attention to on-going state-sanctioned campaigns of mass atrocity, including the companies, foreign and domestic, that facilitated Myanmar's extermination and deportation of the Rohingya (UNHRC 2019). In spite of these promising efforts, United Nations remains devastatingly limited in its ability to protect human rights (Sethi 2015).

The need to include business in these conversations, however, is only increasing. Transnational corporations continue to dwarf the size of many countries. Today, more than fifty percent of the richest entities in the world are corporations, not countries (Global Justice Now 2018). Encouraging corporate participation in the protection of human rights requires supporting corporate leadership in ways that make it more willing and prepared to engage in this work. Public voices increasingly demand this participation.

Impacted and influenced publics advance human rights discourse as much through informal processes of persuasion as through the formal actions of organizations (Niezen 2020). A dialectical relationship must exist between the harmed and the one that committed harm in order to promote the emotions of guilt necessary to compel a response (Makkai and Braithwaite 1994a, b). Victims and their advocates can sometimes instigate corporate engagement with human rights violations. The idea that Unilever, for example, could be considered complicit with the Nazis came late to the company and only due to outside pressure (Forbes 2007). Also due to public pressure, Royal Dutch Shell continues to face questions about its war years operating in Nazi Germany (Boon and Wubs 2016). Publics pressured Hugo Boss to reveal its role in the war. The company responded by commissioning historian Roman Koester to complete an 
independent history. Upon completion of a World War II study in 2011, the company issued an apology (BBC 2011). Scholars Köster and Schnaus (2018) revived attention to the clothing industry's margins of maneuver during the Nazi regime. Hugo Boss made Nazi uniforms; Seidensticker made shirts; and Bierbaum-Proenen made other garments. Company founders Walter Seidensticker and Hugo Boss became early and lasting members of the Nazi party. While they used less slave labor than other industries, each company benefited from the closure or acquisition of Jewish-owned competitors. Hugo Boss flourished, doubling its employees to fulfill the demand for Nazi uniforms. Such histories have increasingly come into public view and shifted corporate ethical discourse.

Contemporary executives who are engaging (willingly or by public demand) with questions about the past first need to understand that they cannot fully control the duration of these atonement conversations. Degussa AG thought it had atoned for its wartime role but finds itself still crippled by its past. During the war, Degussa AG absorbed Jewish real estate and assets, acquired rights to the $\$ 8$ million (in contemporary value) of stolen precious metals, and used forced laborers (most of whom they worked to death). Through its subsidiary, Degesch, the company also produced the cyanide-based Zyklon B pellets used in the gas chambers. The company made an estimated $\$ 168,000$ profit in contemporary value for the sale of Zyklon B (Rosenbloom and Althaus 2010). For this, the director of Degesch received a five-year prison sentence (Gutman 1990; Feig 1981). Other Degesch leaders lost their jobs. Ultimately, international law, through German courts, issued a rare conviction: The court held the entire company accountable for slave labor. In 2000, Degesch worked with sixteen other companies to create a foundation that donated millions of euros to the survivors of its abuses.

The company had hoped their donations and legal convictions would put the past to rest, but survivors do not forget so easily. At the time of the commemoration ceremony for Convoy 77, one of the participating survivors, Cecile, spoke to me about how her father's deportation from France and murder at Auschwitz continues to affect her feelings about corporate complicity: "When I go to the pharmacy, I always look at which brand made the product. The pharmacist always wonders why I ask. But I won't buy a product from a company that participated in the production of Zyklon B gas." ${ }^{2}$ While companies rarely feel the moral or financial pinch of survivors' personal boycotts, they may face their history in other ways. In 2002, when AG Degussa responded to a Request for Proposal (RFP) to provide the anti-graffiti paint for a new memorial in Berlin to honor murdered Jews,

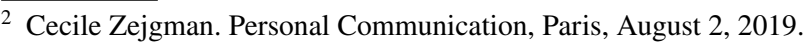

the executive team worried that the lucrative project, valued at just under one million euros, would unearth its past (Rosenbloom and Althaus 2010). This is not an unrealistic fear. Over the past two decades, French National Railways (SNCF- Société Nationale des Chemins de Fer Français) executives watched their wartime history make national and international news as they bid in response to RFPs for highspeed, regional, and commuter rail projects in several U.S. states.

My study of the French National Railways' wartime activities both demonstrates the complex roles these actors can play during war and advances conversations about corporate leadership in the aftermath. The company had multiple roles during World War II; first, as a victim of the German occupation in France. Post-war the company received the title of hero for the acts of some brave employees. Fifty years later, the title of perpetrator circulated as the company's role in the Holocaust deportations became more publicly visible. The SNCF worked to maintain a positive group identity throughout these periods. Initially, trying to maintain esteem within the organization and in the eyes of consumers, sidelined ethical complexities associated with the war. When this happens, superficial work of image management replaces the development of healthy esteem earned through reflection and correction of missteps. Etang (1994) aims to guide leaders through this difference. Many confuse public relations and propaganda; the former engages in a thoughtful on-going two-way (or multiparty) dialogue. Propaganda, on the other hand, seeks only to influence opinion.

Increased scholarly engagement will inspire and guide corporate engagement with human rights protection and atonement. Clohesy (2004) encourages corporations to adhere to human rights standards as an extension of moral duty, most scholars writing about management, entrepreneurship, finance, or accounting sidestep corporate moral obligations. Scholars considering this subject matter rarely discuss historical wrongs. Liu et al. (2019) reviewed the thematic landscape of business ethics scholarship, they identified scholars grappling with ethical decision making (leadership, market and consumer), corporate social responsibility, and philanthropy. An analysis by Collins (2000) identified other subcategories, such as ethical sensitivities, ethics codes, and human resources. Singer (2007) explores scholarship at the intersection of business strategy and ethics. None of these contributions, however, enter into the historical behavior of corporations and its relation to contemporary corporate ethics. ${ }^{3}$

\footnotetext{
${ }^{3}$ Note, some scholars studying the connection of U.S. slavery and capitalism have started to explore this intersection, though focus primarily on past infractions versus present-day accountability. See Caitlin Rosenthal's Accounting for Slavery and Slavery's Capitalism by Sven Beckert and Seth Rockman.
} 
The themes of human rights, mass atrocity, atonement, genocide, complicity, war crimes, historical legacy and even victims remain outside the scope of these inquiries. To date, the most egregious crimes, such as those enumerated in the International Criminal Court's Victim's Handbook, remain unexamined by scholars writing about corporate behavior and strategy. Yet companies continue to participate in murder, torture, pillaging, enslavement and the use of armed groups. The lack of juridical or government bodies at the international level that handle corporate actors and legal lacuna at the state level make the participation of business ethics scholarship imperative. This new conversation fits easily within existing scholarship about ethical leadership. Thankfully, CEOs of major corporations increasingly fashion themselves as activists (Chatterji and Toffel 2018). This activism, which usually focuses on forward change, could also apply to addressing past atrocities. While perhaps less glamourous work, addressing past harm remains an essential aspect of ethical leadership. Just as leaders as well as citizens inherit their country's histories, so too do CEOs and employees. Leadership sets an ethical tone that staff can materialize to great effect (Lempereur and Herrington 2016).

Perhaps this argument moves too quickly for those asking, "can groups be responsible or have moral duties?" (Singer 2007, p. 25). Friedman (1970) and others, who see profit seeking as the only collective responsibility of businesses, challenge this ethics and accountability discourse. Increasingly, however, scholars are pushing back on what seems, to many, like dated logic. Robinson (2009), writing about professional contexts, promotes a standard of "universal responsibility" that asks us "to see the other as of value and thus worthy of our response-always" (2009, p. 18). Following Bauman (1989), Robinson contends that the Holocaust made this a moral imperative. Pruzan (2001) argues that these duties had to be fulfilled through the kind of on-going existential self-reflection needed for honest assessment. I argue that the kind of increased organizational consciousness that Pruzan advocates must also include reflections about past behavior. Who can provide guidance to those at the helm of companies with histories of human rights abuses?

Transitional justice scholars consider amends-making in these contexts. While initially focused on nation-building during the Cold War (Teitel 2003), the field expanded to include various forms of atonement such as compensation, institutional change, victim services, commemoration, transparency, and apologies (Auckerman 2002). While state engagement with these mechanisms remains the focus of most working in transitional justice, corporations increasingly find themselves under scrutiny (Federman 2017). The SNCF serves as an ideal case at the intersection of business ethics and transitional justice, both because of the company's complex roles during the war and its deep engagement with how to respond to its participation in the Holocaust. From the moment of German occupation through the present day, the company's moral actions and inactions can provide guidance to those needing to atone.

\section{SNCF Conflict Summary}

On November 11, 1918, the Allies and Germany officially ended World War I through an Armistice signed in Compiègne, France. After France fell to Germany during World War II, Adolf Hitler wanted the 1940 Franco-German Armistice signed in the same small free-standing railcar that had served as a French tourist attraction between the two wars. This Armistice divided France into an occupied and a free zone while requisitioning the rolling stock of the French National Railways. After the signing, Hitler sent the railcar to Germany for public display. Even without the original railcar, the site remains a poignant symbolic locale for the two nations. During the November 2018 centennial anniversary of the end of World War I, President Emmanuel Macron of France and Chancellor Angela Merkel of Germany unveiled a plaque placed where the railcar once stood symbolizing Franco-German reconciliation. Railcars remain poignant lieux de mémoire (memory sites) in the FrenchGerman psyche, though shifts in memory politics alter what exactly trains symbolize. Today, the French National Railways, long serving as the veins of France and an example of France's world-class engineering, often faces complaints as the French people bemoan the late trains, closed kiosks, long ticket lines, and periodic strikes. Over the past two decades, the SNCF also found itself the site of memory contestation. A group of Holocaust survivors-based first in France, then in the United States, and beyond-demanded that the SNCF make amends for participating in the transport of approximately 76,000 mostly foreign-born Jewish deportees cramped in horrific conditions to the German border where non-French drivers boarded the trains and carried the victims to death camps. Roughly 3500 returned. The SNCF refused to compensate survivors directly, but tried to make amends through transparency, apologies, and commemoration. Lawsuits, first in France and then in the United States, met dead ends. Threats of boycotts kept the debate alive: Those challenging the company used as leverage the SNCF's bids (via its subsidiary Keolis) for regional, commuter, and high-speed rail contracts throughout the United States. Legislation drafted in Maryland, Florida, and California aimed to prevent the company from bidding for state contracts until it made sufficient amends with local survivors. The on-going debates pressured the French and U.S. 
governments to reach a $\$ 60$ million settlement in 2014 to cover a group of survivors not covered by other compensation programs. ${ }^{4}$ Prior to this agreement, the debates kept lawyers, legislators, survivor groups, ambassadors, SNCF executives, historians, Jewish leaders, and others ensnared in debates over the correct response. The SNCF just could not make the problem go away.

French historian Michael Marrus observed that, "the SNCF case has had a global resonance" (2010, p. 263). With so many perpetrators (past and present) unaccounted for, what kept the SNCF the focal point of national and international debates? Part of this resonance can be explained by the fact that the SNCF fits the perpetrator profile. The company has a number of attributes that make it an "ideal perpetrator." The SNCF is (1) strong, (2) abstractable (inhuman), (3) representative of the nature of the crime, and (4) has a champion-opponent who focuses attention on the perpetrator (Federman 2018). When your brand represents the symbol of an atrocity (in this case trains) skirting the past becomes almost impossible. Without denying its participation, the SNCF executives defended the company by claiming its own victimization under German rule. In 2011, SNCF America president Dennis Douté told the press, "assets were plundered and destroyed, its employees and their families threatened, and hundreds of them executed" (Sohr 2011). Some felt these comments from the SNCF suggested a moral equivalency between inanimate assets and people. Others appreciated this acknowledgment of the company's suffering as well as reminders of acts of heroism. This paper examines the identities of victim, hero, and perpetrator as well as the socio-political contexts that allowed each identity to take precedence at different times after the war. In the aftermath, company's refusal to compensate victims prolonged the conflict in ways that arguably proved more productive than issuing checks at the first sign of trouble. While the victims deserve those checks, the prolongation underscored a point too often missed; moral wrongs cannot be undone by simply throwing money at them. In the wake of catastrophic damage, acknowledgment of the harms and a shift in company ethos requires more thoughtful ethical leadership than a check to victims usually indicates.

\section{Methods}

Understanding the French national railways' complex historical wartime required visits to the SNCF archives, the French National Archives, the Hoover Institute, the Memorial de la Shoah and the l'Association pour l'histoire des chemins de fer (the Association for the History of Railroads, or AHICF),

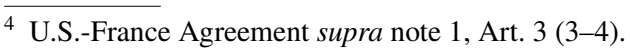

along with secondary source materials. To map the discursive landscape surrounding the conflict, I conducted over 130 interviews with French and American Jewish leadership, SNCF executives, lawyers, legislators, French and American ambassadors, archivists, and historians. ${ }^{5}$ With these experts, I began with structured interviews, though after meeting them for a second or third time, many interviews became conversations. The 90 interviews conducted with survivors who fled persecution in France during the war were less structured. Discussions often meandered for hours (or days) between life histories and feelings about compensation. Attendance at key legislative and commemorative events in both countries, including the U.S. Department of State settlement signing, provided access to infighting among and between groups. Pro bono work with the U.S. House of Representatives, the Department of State, and The Washington Post, also offered deeper access into backroom discussions. As for analysis, I took inspiration from literary theorist Frye (1957) who asked scholars to "stand under" a text in order to understand its meaning. In this spirit, I recorded and stood under the narratives circulating about the SNCF, seeking out conversations wherever they occurred trying not to take sides. I mapped out the conversations to ensuring that I fully understood not only the perspective of each group, but their perspectives about those they believed worked in opposition to them. This discourse analysis approach frustrated some interviewees who preferred me to join in the fight. However, I ultimately contributed more by sharing the meaning making and conundrums faced by various involved parties. This helped increase understanding and bridge the cavernous divide between them. This approach also invites greater reader participation. Responding to these moral dilemmas is a collective challenge. Persuading you to support one "team" over the other perpetuates a binary formulation of the story, which invites simplistic responses to complex situations. Embracing complexity and overlapping positions will more easily inspire deep corporate and scholarly engagement with these issues. The following overview of the SNCF's wartime roles will help contextualize contemporary debates as well as their relevance to the larger question of contemporary corporate atonement.

\footnotetext{
5 More specifically, I interviewed two American Ambassadors and two French Ambassadors working on the conflict, two senior SNCF executives, Jewish leaders in both countries, numerous involved legislators, lawyers, historians, railway industry experts, journalists and archivists.
} 


\section{SNCF as Victim}

Whereas Hugo Boss flourished during the Nazi expansion, the SNCF struggled under its weight. In August 1937, just prior to the war, the French Parliament voted to nationalize the country's railway network, which employed roughly 500,000 workers (Broch 2016). This led to the January 1, 1938 creation of the SNCF, a former conglomerate of five major private rail companies. ${ }^{6}$ Under this new structure, the government controlled the budgets, policies, and board appointments. Robert Henri Le Besnerais, the last general director of the independent Compagnie du Nord line, became the first general director of the SNCF, a position he maintained during the war. He was described as cold and methodical (Bernstein 2019).

In September 1939, in response Germany's invasion of Poland, France declared war on Germany. The Third Reich launched its offensive against France from May through June in 1940 during what became known as the Phoney War (Drôle de guerre). The SNCF transported two million French soldiers to stave off the Germans, saw one-fifth of its railway workers drafted, and repaired twenty-two stations hit by German bombs. Thirty-five thousand SNCF workers were taken prisoner, over a thousand were killed, and many others fled (Broch 2016, pp. 41-49). The SNCF's estimated 515,000 employees at the start of 1938 had been reduced to 400,000 cheminots (railway workers) by May 1940. During this chaotic period, panicked SNCF executives moved the Paris-based headquarters $150 \mathrm{~km}$ southwest of Paris. The rails struggled to transport the two million fleeing French citizens, many escaping Paris. Unable to meet the demand, the SNCF left many would-be passengers waiting at the station (Jones 1984).

Within a month, France had fallen. The Armistice agreement, Convention Franco-Allemande d'Armistice, was signed June 22, 1940. Article 13 of this agreement placed the SNCF under the direction of the Third Reich and required France to make all trains available to the Germans in the occupied territory. The agreement took effect June 25, 1940 and placed the SNCF under the German thumb for the duration of the war. It also divided France into an occupied and free zone to be managed by the newly formed Vichy government. The SNCF became one of the few French entities permitted to pass between the occupied and unoccupied zones. The company ultimately lacked the freedom that this permission to travel might suggest.

As in many hostile corporate takeovers, executives accepted the new terms without much enthusiasm. Soon

\footnotetext{
6 The SNCF's ownership was split between the previous owners who retained a $49 \%$ share and the state, which acquired the remaining $51 \%$.
}

after the Armistice, in September 1940, the Vichy government appointed Pierre Eugène Fournier, previously governor of the Bank of France, as SNCF President. His reputation as a high-performing technocrat helped earn him the position (Bernstein 2019). He ran the SNCF with the help of two obedient technocrats SNCF's general director Robert Le Besnerais and Jean Berthelot, who became the Vichy minister of transport. They collectively acted as an extension of the Vichy government.

In September 1941, Fournier reaffirmed the company's commitment to satisfying German demands (AHICF 2001). The SNCF continued to transport paying passengers, German soldiers, livestock, war materials, and raw materials (coal, etc.). Workers, who for decades felt underpaid for such dangerous work (working on coal-fueled railways was especially dangerous), found themselves under even greater burdens and now with a supervising authority that had no pity for their grievances, as the Germans suspended the unions. Workers made their discontent known in other ways. On December 29, 1942, for example, Münzer, the German responsible for French rail activity, wrote a letter to the SNCF saying, "The spirit of collaboration within the SNCF leaves something to be desired" (Monsieur de Directeur Générale 1943, Federman 2018).

SNCF's rolling stock also moved under German control. By December 1940, over 182,692 SNCF wagons traveled on German rail lines outside of France. The Germans took possession of over 100,000 railcars and over 3,000 steam engines (Jones 1984). Of SNCF's 130 large locomotive depots established before the war, 74 had been destroyed by the war's end (Commission consultative des dommages et reparations 1947). The SNCF billed for all the transports, both to keep the rails running and to demonstrate independence from the Germans. The Germans, however, rarely paid the full monies invoiced. In many cases, the SNCF received roughly half of the invoiced owed. By the summer of 1944, the SNCF faced an enormous financial crisis, operating with a deficit of $\$ 6$ million francs (Broch 2016, p. 143). The Germans understood that the SNCF could operate on a financial loss but could not operate without its railway workers. Therefore, immediately after the armistice, the Germans liberated hundreds of SNCF workers arrested for suspected acts of sabotage, missing identity papers, passing the demarcation line, communist activities, and altercations with German soldiers. By March of 1943, demands of war increased the Germans requested that the SNCF provide 10,000 workers to support German railroads (Wendt 1943). Of the SNCF workers told to serve in Germany, 2700 refused or resigned, the others acquiesced. During the war 2229 SNCF workers died and 443 died in combat during the liberation of France (Fontaine 2017).

Does this loss of control over rolling stock, billing and personnel enable the SNCF to claim victimhood? Some will 
always (and understandably) refuse to see them this way. If not a victim, the SNCF cheminots, for the most part, were not eager participants. While some SNCF employees used the occupation to advance their careers, most simply struggled under the demands of the war and showed no enthusiasm for the occupation. Few had control over their lives. In this way, most SNCF workers acted like the average French person; tired, afraid, and more concerned with their own survival than with the deportation of neighbors. Amidst this weariness and self-preoccupation, how did the SNCF successfully maintain an identity of heroism for fifty years after the war? With State support.

\section{SNCF as Hero}

For many years, even decades, after World War II, the French government consciously chose to brand the SNCF as a wartime hero. Many French emerged from the war hungry and dispirited. The SNCF became a useful site upon which to rebuild the nation's pride. The railway stood as a symbol of strength and efficacy, a perfect post-war metaphor. Some railway workers were true heroes and could be celebrated. Additionally, the esprit de famille within the SNCF might inspire social cohesion among the wider population.

With guns still firing, the SNCF's heroic identity took shape. On August 26, 1944, the same day that Charles de Gaulle-with German snipers still shooting at him—led a victory parade down the Champs Élysées in Paris, the Conseil national de la Résistance, a resistance organization that coordinated different wartime efforts, congratulated SNCF's Fournier for the company's acts of sabotage during the war. The 1947 popular film La Bataille du Rail shows footage of D-day sabotage and celebrates cheminots' heroism. This film, produced with the SNCF and the government, further embossed the SNCF's heroic image nationally and internationally. A leaflet, La Guerre du Rail (1948), also served as powerful propaganda. The galvanizing text trumpets cheminot bravery as well as their sacrifice, equating the destruction of their beautiful, precise machines with an amputation of a part of themselves (Vulpes 1948, p. 16). Though no one challenges the veracity of the D-Day sabotage efforts, Marrus and Paxton (1981) question whether the sabotaging was less about the liberation of France than mere fatigue of being dominated.

During the 1950s, accolades continued for the SNCF. The company received the Légion d'honneur for its acts of resistance, becoming the first company to receive the award (Broch 2016). The government also commissioned Paul Durand, a son and grandson of railway workers, to work as a Committee Correspondent of the Second World War interviewing cheminots who had participated in or witnessed resistance within the SNCF. The resulting book, La SNCF dans la guerre: sa résistance à l'occupant (The SNCF During the War: Its Resistance to the Occupier), presents resistance as a statement rather than a question.

The constructed nature of these heroic narratives does at all not mean that very real acts of heroism by employees of the company did not happen. Within the SNCF, however, heroism occurred below executive level. Oskar Schindler (enamelware) and Frederick Philips (lightbulbs) used their facilities to save others, proving the feasibility of ethical corporate leadership in this dangerous time (Lempereur and Herrington 2016). The SNCF executives provided no such legendary fodder. ${ }^{7}$ The SNCF earned its heroic postwar identity not through its leaders, but largely through the actions of a few railway workers who sabotaged trains during D-Day. In doing so, these brave few helped prevent German armaments and reinforcements from reaching Normandy. While this become the focal point of heroic tales immediately after the war, other important acts of resistance occurred. An overview first requires making a distinction between acts of resistance and from being in the Resistance-with a capital "R." Formal members of the Resistance, through complex networks of communication, produced underground newspapers, created false identities, organized the protection of Allied troops, assisted in various escape attempts, etc. Some SNCF workers participated in the Resistance and some coordinated their own activities. While most did not, those resisted more often sought to liberate France from the Germans than to help the deportees.

Rather than heroes, SNCF executives served as reluctant, albeit effective, extensions of the German occupation. While they billed the Germans for every request, they also engaged their own surveillance, recording acts of resistance by employees or others who interfered with the proper functioning of the railways. Throughout the war, Robert Le Besnerais, the SNCF's wartime general director, reported hundreds of SNCF employees to the Germans (Bachelier 1996). In August 1941, SNCF's Le Besnerais writes, "we must not miss any indicator, any information that can help the police find the guilty parties and those committing acts of sabotage" (Richardot 2012, p. 40). The company's crackdown on acts of subversion decreased the circulation of underground communist papers and other employee-initiated communication. SNCF executives became so effective at eliminating sabotage early in the occupation that they became an example for other government divisions. Jean Berthelot, the head of SNCF transport who became the Vichy Minister of Transport, began advising the postal system how to censor employee communication. The acts of resistance celebrated

\footnotetext{
7 There are differences, of course. Those men could move their factories to more strategic locations, whereas SNCF executives worked with rails stapled to the ground.
} 
after the war were those conducted by the few railway workers who courageously defied company policy.

The SNCF workers had no official "Resistance" organization, though other resistance groups often recruited them for their knowledge of the rails and the timing of many activities. Their response to recruitment was mixed; as political moderates committed to their trains, they were not historically prone to destroying them or involving themselves in political disputes (Broch 2016). Those who wanted to participate sometimes facilitated plans of other groups. Some engaged in symbolic acts such as making jokes about the German occupiers or painting a V for Victoire or other symbols used by Gaullist or Bolshevik supporters (Broch 2016). Some altered signs to send trains filled with German soldiers to the wrong location or slowing trains. The esprit de famille, family spirit, within the company and the values of duty and loyalty kept the workers united in their task of maintaining a functioning railroad (Broch 2014). This hierarchical family structure, which existed before the war, helped employees feel safer during a time of great uncertainty. In exchange for this security, the employees most often simply followed orders.

Regarding the deportations, one sees even less resistance. Henry Rousso found that whatever margin of maneuver the SNCF workers had, they used it infrequently to assist the deportees (AHICF 2001, p. 352). The archive in the central office of German security that recorded all details of the deportations said all went smoothly in France. The SNCF went to great lengths to ensure on-time departures. That said, a few SNCF workers helped deportees physically or morally and likely many acts went unrecorded. Early on in the deportations, railway workers could collect bits of paper jettisoned out of small openings in railcars which they mailed. This small act profoundly affected some recipients. Henri and Simone Fanny Blum threw out a note which read, "We hope the children are okay. We hope they are in good hands." Pierre Blum, now in his late $80 \mathrm{~s}$, still grieves that his sister lost these last words from their parents. ${ }^{8}$

Some employees assisted with escapes. Raymond Zaks said, "My life is indebted to the railway workers and the Resistance!" His family tried to escape via the trains and thanks to a railway worker who told them to board after the whistle blew, they rode for free. ${ }^{9}$ The largest coordination of SNCF efforts on behalf of the deportees has recently come to public attention. During a large round-up in Lille, a woman beseeched an SNCF worker to save the children, including her own. Without detection, he and other cheminots responded saving a few dozen children whom they hid in

\footnotetext{
${ }^{8}$ P. Blum, personal communication, August 12, 2014, Paris.

${ }^{9}$ R. Zaks, personal communication, July 29, 2014, Paris.
}

an old dormitory. The SNCF workers, including the station manager, then raised funds for the refugees (Celerse 2016).

Those who engaged in acts of resistance likely created some cognitive dissonance for those who knew about them and did nothing. They provided a moral mirror to those who simply complied. They had to endure the title of "terrorist" and risk loss of life (and possible the lives of their families). The acts of a brave few, however, could not prevent the SNCF's role in the Holocaust.

One wonders how decades of heroic tales affected those cheminots who witnessed and/or participated in the deportations. They likely experienced what Brown and Jones (2000) might consider a belief/act discrepancy. Whether they, as individuals, handled this discrepancy with the hypocrisy, self-deception or scapegoating (identified as techniques by Brown) we may never know. Unfortunately, Durand never asked these questions of his interviewees. Or if he did, he did not record the answers. At an institutional level, self-deception seemed the first line of psychic defense. This defense lasted for the first five decades after the war. During this time, the SNCF became what Nora (1989) would call a lieux de mémoire, or memory site, for the Résistance. We know that individuals need to maintain a positive sense of self to maintain esteem (Brown and Jones 2000; Greenwald 1980; Erez and Earley 1993). Nations and businesses have the same psychic demands. Tales of glory often work to uphold esteem. These narratives can become what Hobsbawm and Ranger call invented traditions. These new traditions aim to, "establish continuity with a suitable historic past" (1983, p. 1). Unfortunately, these invented traditions can thwart the crucial reflection needed to catalyze moral growth. Arendt (1998) and Jaspers (2001) urged post-war Europe to undergo this critical albeit uncomfortable reflection. But this would not happen in France or within the SNCF for quite some time.

\section{The SNCF as Perpetrator}

The nature of the SNCF's role in the deportations became public far more slowly than stories of heroism. Once illuminated, this image of the SNCF as a perpetrator remained in the public eye, even in the United States. Harrowing stories emerged of people being shoved into cattle cars to suffer often for $36 \mathrm{~h}$ with little air, no light and often without water. Lawsuits first in France and then in the United States raised awareness of these stories so long buried under heroic tales. The SNCF's role as perpetrator became a question of U.S. governmental concern when on July 30, 2013, New York Senator Charles Schumer presented the Holocaust Rail Justice Act to the U.S. Senate. This bill sought to enable litigants to circumvent the U.S. Foreign Sovereign Immunities Act (FSIA) which protected the state-owned railway 
company. The accusations include claims that the French National Railways during the Second World War:

(1) operated independently,

(2) collaborated willingly,

(3) determined the conditions, cleaned the transports and

(4) conducted the trains that carried these deportees and over 75,000 others for a profit. ${ }^{10}$

As accountability discussions require a full understanding of what occurred, the following briefly reviews these claims.

The Holocaust Rail Justice Act claims that the SNCF acted independently. Only 6000 Germans monitored the roughly 515,000 SNCF workers the company employed at the beginning of the war in 1938 (Broch 2016, p. 38). With so few German overseers, insiders became vital accomplices (Marrus and Paxton 1981, p. 16). The French largely ran their railroad on their own while meeting German demands until November 1942 (Margairaz 1998). Once France became fully occupied, the SNCF retained control only over daily management, not executive planning (Bachelier 1996).

The bill also accuses the SNCF of organizing the deportations. Germans ordered the deportations which Vichy, the French Police and the SNCF enacted. The SNCF cheminots who organized, managed, and drove the deportee transports as far as a town called Novéant, about one hundred kilometers from the German border (Ribeill 2008, p. 45). In 1942, Eichmann invited to the Reichssicherheitshauptamt (RSHA), the German High Security Office in Berlin, the individuals organizing the deportations in France, the Netherlands, and in Belgium. These meetings included the Vichy government, the occupier, the French police and an SNCF technician who together determined how 100,000 Jews would be deported from both the occupied and unoccupied zones (Marrus and Paxton 1981; Hilberg 2003). For discretion, the SNCF technician suggested calling these trains, Transports IAPT (Israelites, Allemand, Polonais, Tchèque). The delegation decided the deportation trains would depart from smaller rail stations early in the morning (between 6am and 7am). These acts of discretion demonstrate that the delegation knew full well the harm they were about to inflict. They wanted as few witnesses as possible. Surely, the horrified looks of bystanders would serve as an uncomfortable mirror.

When SS Captain Theodor Dannecker (representing Adolf Eichmann in the RSHA in charge of Jewish matters) returned to Paris on June 15, 1942, he communicated the deportation plan to the French authorities, cutting the number in half, to 40,000. Dannecker maintained regular contact with the Haupt Verkehrsdirektion (HDV) in Paris, the German division overseeing the SNCF. SNCF workers

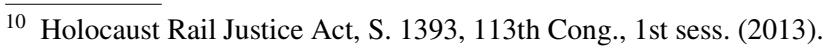

corresponded with the local French prefectures about a series of "special" trains. The Vichy government and the SNCF's senior executives became increasingly involved in the deportations. By the summer of 1942, Vichy organized the wagons and the local prefectures managed the transports as well as the refueling (Bachelier 1996). French train drivers and French police took the deportees to Novéant-surMoselle, near the German frontier, roughly $300 \mathrm{~km}$ from Paris. Non-SNCF drivers (often German or Polish) transported them from the border to the death camps (Marrus and Paxton 1981, p. 259). The RSHA (Reichssicherheitshauptamt) department handled some of the logistics.

The Holocaust Rail Justice Act asserts that the SNCF determined the horrific conditions in which the deportees traveled. First, a note about railcars used. Within France the SNCF transported deportees from round-up locations to various internment camps mostly via third-class passenger cars. The first convoy that left France for Auschwitz in 1942 was also a third-class passenger train, as was the last train departing from Lyon (Convoy 78). When he became responsible for the Final Solution in France, SS Captain Theodor Dannecker issued orders that the deportees would travel in what we now call cattle cars. Those seeking cost efficient removal of the Jews found third-class passenger trains too small and too expensive. In addition, the Germans found the many doors and windows in passenger cars harder to guard; passenger trains required two hundred guards. As a result, the second convoy departing June 5, 1942, and subsequent convoys, carried deportees in cattle cars that required far less supervision and were far harder to escape (Wieviorka 2007). These convoys offered little air, no light, usually some small amount of water, and a barrel for sanitation. Any provisions received often proved barely edible for man or beast; rotten tomatoes and fruit often made them sick. Salty provisions proved too risky with so little water. The SNCF did not seem to be included in the conversations about the quality or quantity of food provided to the deportees.

By 1944, the number of deportees crammed into the cars had doubled in some cases and even quadrupled (Ribeill 2008). No longer could people sit during the multi day voyage. Increasingly deportees had "soft" deaths, caused by asphyxiation, hypothermia, freezing to death, or thirst. They sweltered in the summer and froze in the winter in traveling in wooden merchandise containers. Air openings, when present, were often small and well above eye level. Without shock absorption, the wagons threw the adults, children, babies, elderly, and the handicapped from side to side, occasionally breaking bones. One convoy, later named Le Train de la Mort (the train of death), departing from Compiègne, arrived at Auschwitz with five hundred dead. While the SNCF did not determine these conditions, the executives did not seem to resist them. Archival documents showed resistance to German billing more generally, 
but nothing regarding resistance to the quality of transport for the deportees.

The Holocaust Rail Justice Act also claimed that the "SNCF cleaned the trains after each trip, removing the corpses of persons who perished during transit due to the execrable conditions of the train cars" (2013). Not so. Even those cars that had been stopped and cleaned mid-journey appear not to have been cleaned by SNCF workers. This was primarily because the SNCF workers did not travel with the trains to their destination. Francis Rohmer, head of Clinical Neurology at Strasbourg's School of Medicine, survived a brutal voyage from Compiègne on July 2, 1944, to the Dachau concentration camp. Rohmer recalled the train stopping just beyond the northeast French town of Revigny-surOrnain. The doors opened and those in charge yelled "Raus, Schnell!" [Get Out, Quickly!] The living descended. Then, he says, "They put in our car the dead from the neighboring wagons.... Once the transfer of dead was completed, they had us get into another wagon that was bigger..." (Ribeill 2008 , p. 39). The voyage alone killed 984 people. Even when the horrific task of cleaning out the corpses was performed mid-trip; SNCF workers did not seem to be involved.

The lawsuits and legislation targeted at the SNCF often prompted question, did the SNCF know the destination? During the war, deportees waiting at the Drancy internment camp outside of Paris would say they were off to Pitchipoia Yiddish word meaning some unknown destination. Who could have imagined such a terminus? Eventually, word spread about the camps. J'Accuse, an underground French newspaper circulating in the Drancy internment camp, informed internees about their most probable future. As early as 1942, the paper reported that torturers "are burning and asphyxiating thousands of men, women and children deported from France" (Bretholz and Olesker 1999, p. 152). Once deportees knew, then SNCF senior executives also likely had a fairly good understanding of the Nazi plan to exterminate the Jews, as did the railway workers whose underground press discussed the Jewish persecution (Broch 2016, p. 193). But it is, of course difficult, to know what every cheminot who worked close to those deportations knew. At the very least, the horrific travel conditions suggested a dark destiny.

When litigants and advocates can prove profits, they strengthen their claims of corporate legal liability. The Holocaust Rail Justice Act sought to make this connection, proclaiming that the "SNCF allegedly charged an ordinary passenger coach fare for the deportations, calculated per person and per kilometer, and considered these trains as ordinary commercial activities" (2013). Responding to this claim requires addressing two questions. First, did the SNCF profit from the German occupation? No, unlike Hugo Boss and others, the SNCF lost money during the war. What people really want to know is whether the
SNCF billed for the deportations. Payment for the deportation varied by country. In some cases, the Reich Security Main Office (RHSA) paid the invoices for the deportations. The money used to pay these invoices, however, often came from taxes imposed on the Jews (Hilberg 1961). In some cases, through taxes or forced ticket purchases, Jewish deportees paid for their own deportation. Croatia, in contrast, paid Germany to remove its Jews. October 9, 1942, the Croatian Finance Minister Koshak agreed to pay Germany 30 Reichsmark for each Jew removed. In France, French taxpayers likely paid for the transports via German-imposed taxes (Hilberg 2003, p. 764). Bachelier (1996) concluded that the SNCF billed Germany and received payment for all of its services. The only pro bono work he found was the SNCF's offer to carry prisoner of war (POW) Christmas parcels. The SNCF issued invoices for a number of internal transports, meaning transports that occurred within France (i.e., to internment camps). Some of the invoices discovered are dated after D-day. On December 22, 1944, for example, the Prefecture of HauteGaronne forwarded an invoice from the SNCF for 210,385 francs issued for the transport of "detailed and evicted" persons from his department, likely to Drancy. He sent the invoice to an accounting office in Paris.

Given the numerous invoices in the SNCF archives documenting the numerous transports of passengers, soldiers, armaments, goods, students, and others, remarkably little exists about the deportations. As of 2019, only two known documents address the transport of Jewish deportees from France to Auschwitz. One invoice passed between two German agencies: The Gestapo and a German travel agency. The Travel Office sent the invoice to the Commanding Officer Ministry (the Gestapo) for the movement of this "Special Jewish Train," noting that the train would not operate on a normal schedule. The invoice billed for the transport of 1500 Jews from Bobigny to Auschwitz and calculated the rate using the metric per person, per kilometer. This invoice suggests that payment for at least some of the transports occurred between German divisions and did not include the SNCF. Another document discovered in the departmental archives of the Loiret suggests the SNCF billed, at least sometimes, for these transports. The September 15, 1942 document from the SNCF to the Loiret prefect refers to four trains that left from France to Auschwitz. The letter asks to whom the SNCF ought to send the invoice, to the prefect or to the Minister of the Interior (Bernstein 2019). During interviews, some asked, "Would it have been better to transport the deportees for free?" The refusal to accept payment would have been an important moral decision. At the same time, not charging the Germans would simply have saved the German's money. Which decision was the moral one? The SNCF clearly did not initiate the deportations, nor did it express the same enthusiasm for the Nazi regime as the 
German National Railways. At the same time, neither did the company seem to resist. This murky role may enable SNCF to continue to skirt legal liability as it did in France and the United States, but not necessarily moral responsibility. The following examination of SNCF's executive leadership, not included in other discussions of the debate, points to the crucial role of ethical corporate leadership and where the SNCF executive team failed.

\section{Ethical Leadership Under Occupation}

Even though International Military Tribunals at Nuremberg focused exclusively on individual executives, the contemporary SNCF debates never focused on individuals. Dead executives cannot go to prison. There were, however, some early attempts to hold a few accountable: Immediately after the war, the Vichy Minister of Transport, Jean Berthelot, stood trial. In his own defense, Berthelot attested that as a technician he was beyond reproach (Bernstein 2019). Le Besnerais was simply moved into retirement. Fournier continued to run the SNCF for several years after the war, allegedly allowed to continue to help stabilize post-war France. The Vichy choice of Pierre Eugène Fournier to run the SNCF affected the destinies of many. Fournier, the former head of the French Bank, had a reputation for being honest, straightforward, rigid, and a patriot. These qualities made him a useful pawn for the German agenda, at least initially.

Fournier played a significant role in purging Jews from French society. From 1940 to 1941, while serving as SNCF president, the Vichy government appointed Fournier as the first director of SCAP, Service de contrôle des administrateurs provisoires (service for the regulation of provisional administrators). This government office aimed to eliminate all Jewish influence on the economic life of France (Verheyde 1999). SCAP forced Jewish business owners to sell their businesses to an Aryan. Upon taking the position, Fournier announced to the other administrators of SCAP: "This is a public service mission.... It demands tact on your part, you will often find yourself in the presence of difficult situations; you will need to avoid brutality and upsets that distract from the larger mission that you have received" (Richardot 2012, p. 76).

Fournier, compensated for his work within SCAP, proved highly effective at his mission. At the beginning of Fournier's term, Paris had roughly 11,000 Jewish businesses (Adler 1987). Fournier had successfully Aryanized over 4,500 Jewish businesses in order to meet the German deadline of December 26, 1940. SCAP's work resulted in the acquisition of over five billion francs (Richardot 2012). This included assets taken from the Rothschild family which maintained a financial stake in the SNCF. Fournier eventually resigned from SCAP because he despised German authorities meddling in his work, rather than because he had any sympathies for the Jews. Fournier continued to support the Vichy Regime and its Head of State, Philippe Pétain, as a means of asserting French independence. On June 6, 1944 (D-Day), the Germans arrested Fournier for being troublesome and held him hostage for a week. He was then released. No known documents suggest that Fournier resisted his role in SCAP or the deportations.

Today, few histories of the SNCF offer more than passing acknowledgement of Fournier, yet his leadership mattered. Imagining another kind of leader helps make Fournier's ethical lapses more visible. Had Raoul Dautry become director general of SNCF, instead of Fournier, the company as a whole may have rightly earned the title of wartime hero. From 1928 to 1937, Dautry served as director general of what was then the State Railways (Chemin de fer de L'Etat). In 1938, when the state created the SNCF, the state relegated Dautry to a member of the governing body. Why might Dautry have made different decisions than Fournier, the stateselected technocrat? Before France fell to Germany, Dautry served as the French minister of armaments, working closely with the British to defeat the Germans. Ten days before France signed the Armistice, placing the country in the hands of the Germans, Dautry wrote the French Council of Minsters imploring France to fight for victory, "Everyone needs to join the fight [against the Germans] regardless of the consequences" (Dautry 1951). Dautry called upon his countrymen to evacuate French industrial sites and rebuild them abroad in the United States, England, Canada, and Northern Africa to build up our armaments necessary to Germans. He might not have so easily acquiesced to the German demands during the occupation or found ways to further advance resistance efforts. Sidelined from central SNCF management during the war, Dautry instead spent the occupation working in the south near Côte d'Azur. After the war, he received the Legion d'honneur for his efforts to prevent the Germans from acquiring the ingredients needed to build an atomic bomb (Olson 2017). Almost as if the modern-day SNCF wished Dautry had been its wartime president, Paris commuters pass through Raul Dautry plaza next to what long stood as the SNCF headquarters in Paris. Fournier's name can be found nowhere. Ultimately, the qualities of honesty and patriotism that made Fournier appealing to the French government also made him more compliant to the demands of the occupier. Both men demonstrated loyalty to their country and to the SNCF, though their expression of that loyalty took a very different form. When looking for ethical leaders, qualities of loyalty, rigidity, diligence and even some forms of patriotism may be red flags. Yet even with Fournier's complicity, for decades after the war the SNCF maintained its heroic identity. 


\section{SNCF's Corporate Accountability for the Holocaust}

Several socio-political and economic changes catalyzed the SNCF's loss of heroic status. This loss might be somewhat overstated. Better put, the SNCF eventually found itself forced to also address the less glorious aspects of its wartime role. In the 1980s and 1990s, amidst what became termed "merger mania", notions of corporate governance shifted in the UK and France (Maclean 1999). Codes of best practices emerged first in the UK and reverberated in France where a slew of embarrassing business scandals continued to surface, by 1996, "a quarter of the bosses of France's top 40 companies were under investigation for fraud or corruption" (1999, p. 92). These companies included Société Générale and the SNCF, both complicit in the destruction of Jewish presence France. The resignation of five of French President François Mitterrand's cabinet members over business dealings made the connection between politics and business more visible. Some members received prison sentences. Maclean notes "Mitterrand presided over an 'era of sleaze' with which he, himself, was not untainted" (1999, p. 177). Mitterrand would also emerge as a protector of German collaborators. Prior to this period, matters of corporate governance had been largely ignored; in fact the term did not yet exist. Etang observed that, "the effect of greater awareness of corporate social responsibility and corporate obligation had the effect of entangling corporations in a web of moral discourses which they cannot escape or deny (1994, p, 118)." The SNCF found itself caught in this discursive web. Total confidence in the SNCF's integrity slipped.

Corporations also found themselves in the spotlight when the fall of the Berlin Wall opened the floodgates of Holocaustrelated claims and litigation (Neuborne 2012). ${ }^{11}$ The Allies of World War II, including Switzerland, no longer needed each other for protection from the USSR. In this climate, the unfinished business of the war resurfaced. Prior to this turn, most corporations complicit with the Nazi regime had been "immune," facing no legal accountability (Bilsky 2017, p. 35). Now, the banks came under scrutiny as did the SNCF. Survivors conducted much of this work. Schaechter (1999), orphaned by the Holocaust, became the first to publicly take on the French railway giant. In the early 1990s, Schaechter secretly copied 12,000 documents from the Toulouse archives from the years 1938 to 1949 , including the invoices the SNCF issued to the French government. He announced his findings to the media and caused quite a stir. In 2003, when Schaechter had reached age 82 , a court heard his case. ${ }^{12}$ Suing for a symbolic euro, his lawyer Joseph Roubache argued that the SNCF exceeded German orders and that the company's use of code names for the deportation trains indicates that they knew the nefarious nature of these transports. Roubache also argued that SNCF workers closed and locked the convoy doors and discouraged volunteers from giving food and water. The court dismissed the case citing a ten-year statute of limitations. Yet, Schaechter's highly publicized lawsuit made other claims audible.

Soon after, Jean-Jacques Fraenkel, president of Offshore Coordination of Deported Children, issued a complaint against the SNCF for crimes against humanity (Curran 2008). He sought international recognition from the SNCF and French government for their crimes, through which he would pay tribute to his family (Remy 1998). In 1998, the court dismissed the case for insufficient evidence. The lawsuits kept coming. The most prominent French case, that of the Lipietz family, almost succeeded. The case outlived the defendant and ended with a court ruling that the SNCF's limited liability status placed the company back under the French government. Because of the lack of class action lawsuits and contingency fees in France, anyone taking on the SNCF had to pay all of their legal expenses upfront and launch cases individually. Some, like Lou Helwaser, who was seeking justice for the deportation of her mother, took the financial risk. She lost the case and her money. She and others holding any lingering hopes for justice in French courts after the Lipietz trial likely surrendered them when the Conseil d'Etat (the high court of France that rules on administrative matters) issued a decision in Hoffman-Glemane $v$ France and SNCF. This decision, issued in February 2009, closed all French courts to Holocaust-related cases. The failure of French courts to hold the SNCF liable could also be interpreted as a simple lack of judicial will. The courts remained unimpressed with the SNCF's wartime actions on behalf of the deportees, but never held them liable. As in many cases, had the courts wanted to find a way to hold the company liable, they likely could have.

In spite of the French courts' unwillingness to hold the SNCF liable, the cases unleashed a chorus of demand. Eighteen hundred people launched complaints against the SNCF (Marrus 2010). The SNCF President of the time, AnneMarie Idrac, personally received an estimated 200 letters demanding compensation from survivors and their descendants around the world. While externally the SNCF's heroic reputation was being tarnished, historian Georges Ribeill observed that discussing "deportations" remained taboo within the SNCF through the end of the 1990s (Lerchbaum and Nahum 1999). Eventually the SNCF did respond.

11 B. Neuborne, personal communication, October 17, 2017, email.

12 Tribunal de grande instance [TGI] [ordinary court of original jurisdiction] Paris, May 14, 2003, 2001/07,912. 


\section{SNCF's Response}

Even if they could escape a judicial ruling, the SNCF could not hide from these attacks. Executives, while still refusing to compensate survivors, worked towards transparency, education, commemoration, and other forms of amends-making with survivors. Note, these are all transitional justice mechanisms, though the company did not refer to them as such. When the first accusations emerged in 1990s, SNCF Chairman Louis Gallois commissioned an independent report on the company's wartime history. Conducted via the CNRS (Institut d'Histoire du Temps Présent), Christian Bachelier worked for four years to produce what became known as the Bachelier Report. The SNCF made this report available to the public. The company also opened its archives, added commemorative plaques, held a colloquium about its history and contributed over $\$ 12$ million to Holocaust education, becoming the leading sponsor of the Paris-based Fondation pour la Mémoire de la Shoah (Federman 2018). The SNCF also helps sponsor the annual Reading of the Names events that opened this article. Today in France, the SNCF logo can usually be found wherever Holocaust-related exhibits appear. The company also donated land at Bobigny, the site from which majority of trains departed. A commemorative event held at the site included prominent survivors and leaders in the French Jewish community. SNCF Chairman Guillaume Pepy stood before them and expressed his regrets for the company's past. These efforts satisfied much of the French Jewish leadership. Those believing the SNCF's work remained incomplete without direct financial compensation sought to gain leverage against the company via the United States.

\section{SNCF's Accountability in the United States}

With the French courts closed and much of the French Jewish leadership satisfied with the SNCF's efforts, the U.S. Class action lawsuit system provided another avenue for survivors eager to pursue the company. New York-based lawyer, Harriet Tamen, who had worked on the French Banks class action lawsuit, launched her first lawsuit against the SNCF in 2001. ${ }^{13}$ Tamen criticized the SNCF for trying to rewrite history and remained convinced that the SNCF received payments for the deportation transports. She wanted the SNCF to say, "We are sorry for what we did, we accept responsibility, and we will pay." The courts dismissed the case, claiming that the Foreign Sovereign Immunities Act

13 Abrams v. SOCIETE NATIONALS DES CHEMINS, 175 F. Supp. 2d 423 (E.D.N.Y. 2001).
(FSIA) protects government-owned enterprises. ${ }^{14}$ The lawyers knew that the FSIA would block the case, but used the lawsuit to raise awareness of the conflict. They later would try using the Alien Tort Statute (ATS). The ATS has often been employed by litigants aiming to hold corporations accountable for human rights violations (Skinner 2008). In the SNCF case, these efforts too met a dead-end. The plaintiffs' lawyers had hoped that hoped that the media coverage would generate enough public pressure to convince the SNCF to settle out of court. The SNCF did not settle, but the case did attract significant media attention in France and in the United States.

Sanction threats and social disapproval further pressured the company. The SNCF met the most resistance in Virginia, California, Florida, and Maryland where local groups challenged its bid for local railway contracts. Litigants and activists persuaded legislators to draft legislation pressuring the company to make amends before doing business in their states. In Maryland, legislation passed requiring the SNCF to digitize its World War II archives before bidding for the MARC commuter rail project (Federman 2017). ${ }^{15}$ This settled the issue until the SNCF bid for the Purple Line metro project that extended the federally funded D.C. metro system into Maryland. When Maryland legislators demanded direct compensation for their resident survivors, the Department of State (DOS) intervened. DOS told Maryland legislators if they continued to press for compensation, which they considered conducting diplomacy, the federal government would no longer invest $\$ 900$ million in the project. Not wishing to lose the funding or displease survivors in their states, the Maryland delegates threw the bill in two committees and let it die. The public tussle, however, pressured the French government and the DOS to hurry up and finalize an agreement in 2014 whereby France paid $\$ 60$ million to cover a group of survivors not covered by other compensation programs. ${ }^{16}$ The agreement signing took place at the DOS amidst a small group of lawyers, government officials, survivors, advocates, and members of the press. At the event, lawyer Harriet Tamen vowed to her team to continue fighting the company.

Recipients of the compensation signed a release promising to end the litigation and legislation against the SNCF. Some had mixed feelings. Stanley Kalmanovitz received $\$ 204,000$. His father was gassed at Auschwitz upon arrival from France. Stanley said about the settlement;

\footnotetext{
${ }_{14}$ See Abrams v. SOCIETE NATIONALS DES CHEMINS, $175 \mathrm{~F}$. Supp. 2d 423 (E.D.N.Y. 2001).

15 H.B. 520, 428th Gen. Assem., Reg. Sess. (Md. 2011).

16 U.S.-Fr., Dec. 8, 2014, T.I.A.S. No. 15-1101.
} 
The money came at a good time in my life. Having not expected to live this long, I was close to running out of money. Of course, I am grateful, BUT this is not a settlement of conscience, this is a commercial "gamble" settlement. The opportunity to be awarded large construction contracts was the guideline, not anything else. ${ }^{17}$

When I wrote to schedule another interview, Stanley's son responded informing me that his father had passed.

From the press coverage of these debates, one might think that all French survivors sought amends from the SNCF. In fact, over $80 \%$ of the 90 survivors interviewed for this study had no interest in challenging the SNCF. Those survivors residing in France explained their disinterest in the conflict by emphasizing the SNCF's overlapping identities during the war and some brave cheminots in the resistance. For example, Daniel Urbejtel, deported with his brother, similarly did not begrudge any inactivity on the part of the cheminots, "I do not see that we can reproach the SNCF, in particular the drivers of the trains...I think the SNCF was simply under constraint, just as I [at Auschwitz] worked under constraint, though of course under other conditions."18

U.S.-based survivors whose families faced persecution in France often expressed disinterest in punishing today's French taxpayers for "the dirty deeds of their parents." Stanley Kalmanovitz, who spent his adult life in the United States asked, "What was the French railroad supposed to do? Someone has the gun at your head, what do you do? You take the bullet? Then if everyone takes a bullet then who's left?" ${ }^{19}$ While fewer in number, those who sought justice for the SNCF's role in the deportations advanced their cause as well as business ethics discourse. Their unwavering claims against the company demanded attention, not only to the past deeds, but also to the ethical requirements of the company leaders who inherited this past and the harm it created.

\section{Lessons for Corporate Leadership in the Aftermath of Mass Atrocity}

Corporate executives and scholars can take many lessons from the SNCF conflict. That is why I was surprised when SNCF's former head of Corporate Social Responsibility, Bernard Emsellem, told me that no executives facing similar conundrums reached out to him. He knows well the challenge of repairing irreparable harm. The SNCF also now

\footnotetext{
17 S. Kalmanovitz, personal communication, June 16, 2017, phone and email. Emphasis added.

18 D. Urbejtel, personal communication, August 11, 2014, Versailles, France.

19 S. Kalmanovitz, personal communication, June 16, 2017, phone.
}

knows that what satisfies some victims will not satisfy all. They were at times exasperated by their inability to make peace. After several years of conversations, I eventually encouraged SNCF executives to accept Walker's (2006) advice: Those who participated in mass harm must accept a certain amount of on-going outrage. No amount of compensation or series of collective actions can make up for, say, torture or the murder of one's family.

SNCF's slow acceptance of its more complex wartime role also highlights the importance of victim voices and their supporters. The Dutch National Railways faced similar accusations, and likely because they saw the SNCF's endless troubles, chose to simply pay survivors and their descendants. Ironically, by not paying the survivors, the SNCF became more intimately involved with the damaged caused. Had SNCF executives simply paid survivors as if it were an invoice, they would likely not be so involved in Holocaust education, commemoration, and transparency. The company executives became more involved; some laid wreathes at ceremonies and read reports about what their predecessors had done. In 2010, SNCF President Guillaume Pepy took a trip to Auschwitz with Jacques Fredj, director of Centre de Documentation Juive Contemporaine et Mémorial de la Shoah. In multiple individual meetings with Bernard Emsellem and SNCF America CEO Alain Leray, I listened to them grapple with their employer's past. Both executives are Jewish and lost family in the Holocaust, a strange and perhaps strategic irony. This added the difficult personal work of trying to reconcile multiple conflicting identities. They engaged in it, sometimes willingly and sometimes less enthusiastically.

The deep struggle I saw in the leadership also existed among some SNCF workers, but not all. During a cocktail hour at a railway conference held in Paris, a few SNCF staff, learning about my interest in the company's role in the deportations, literally turned their backs. One chastised me saying, 'I'm Jewish, I work for the railway and I' $m$ very proud." He marched away, refusing to speak to me again. A more widespread internal engagement with the issues required union participation. The unions mostly avoided the topic as this tainted past affected their pride. Engagement at the top could have found other ways to involve more employees. Isolating the issue to the senior management might reflect more equivocal feelings than public actions suggest.

Some other efforts (or lack thereof) suggest a lingering ambivalence about these acts of capitulation. Firstly, a look at SNCF Chairman Guillaume Pepy's expression of regret at the Bobigny commemorative site. Koehn (2013) advocates for corporate apologies that focus on bridge building and trust restoration. Pepy's words had a mixed reception. While lauded at the event by the carefully chosen audience, many survivors living in both countries expressed disappointment. They said expressing "regret" is not an apology. The national 
apology given by former French president Jacques Chirac in 1995 set a high standard that Pepy's did not meet. Likely the fear of legal liability constrained Pepy's expression of remorse. A direct apology suggests liability and the company did not want to pay. This highlights a challenge facing everyone issuing apologies: the question of sincerity. Sincerity concerns shows up in what Sluzki et. al (1976) call the double-bind. In colloquial terms this means, "damned if you do, damned if you don't." When they apologized in France, some said it was not strong enough. When the company apologized in the United States, a group in Florida refused to accept the apology saying it was motivated by business interests in their state. Yet, when the company offered no apology, it was critiqued for not caring. We can look for evidence of sincerity, or lack thereof, in other ways. For example, eight years later the Bobigny commemorative site remains unfinished. Was the land donation, the event, and the apology just to appease the French Jewish leadership? Perhaps so. Daniel who was deported from that site would like to visit the promised memorial before he passes, but cannot yet do so.

Other small indicators suggest unfinished accountability work. In 2017, the SNCF published a 2000-page memorial report produced under the direction of historian Thomas Fontaine. The report details the stories of each SNCF worker who lost his life. The title, Cheminots Victims de la Répression (Railway workers victims of the repression) neglects to highlight that the "repression" was often that enforced by the SNCF executives. During the war, SNCF's Le Besnerais handed a list of 1290 suspicious SNCF workers to the prefectures who then arrested, and at times deported the cheminots. The SNCF also transported French resistants and other political prisoners to concentration camps.

Those seeking amends from the company also missed some opportunities. Overall, they did the important work of prompting what Volkan (2006) calls the "large group mourning process." They succeeded in the shaming, but not in what Makkai and Braithwaite (1994a, b) call "reintegrative shaming." These scholars argue that when businesses engage in accountability processes in helpful ways, they need praise. Some, like Holocaust activist Serge Klarsfeld, eventually offered that praise to the point of serving as their lawyer. Others, like lawyer Harriet Tamen, remained committed to pursuing the company. A more positive future requires acknowledging attempts to atone, even if forgiveness cannot be granted. The trains are not going to disappear; therefore, ways of coming back together must be found.

\section{Conclusion}

Responding to harm is not a linear process. It offers throughout, however, an opportunity for affected parties to engage in a relationship now defined by a presence of morality rather than by its absence. The conversation is not timebound. In this spirit, this article sought to highlight important lessons for those seeking accountability as well as those leading companies during periods of violent conflict, occupation, or war. This study demonstrates that ethical leadership requires taking responsibility, even for those violations occurring before one's tenure. This leadership also requires deep introspection, asking, for example, how might the company ethos have facilitated this participation? What can be done to ensure this ethos has shifted in a positive direction? Within the SNCF, the admirable esprit de famille, which for many put company before nation, expedited participation in ethical catastrophe. Other businesses (clothing industry, chemical companies, and others) seemed to have no ethos preventing them from using war as a business opportunity. Shaming efforts by victims cannot ensure the deep introspection required to make amends and ensure a stronger future. This requires internal leadership.

Scholars can help guide this work. Contemporary corporate executives usually grapple in isolation with the complex or downright sordid histories they inherit. As a result, their focus often becomes a public relations and legal strategy rather than a deeply thought out approach to moral leadership. Without international institutions to help, scholarly engagement is all the more pressing. Without our engagement, businesses may have the impression that ethical standards do not apply to them and simply react defensively when exposed. Popovski advocates for a Corporate Responsibility to Protect (CR2P) but this and related movements need support. The increasing size and reach of corporations make moral voices increasingly vital. Business ethics scholars and practitioners can help be part of that voice, engaging business leaders and supporting the private turn of human rights.

Open Access This article is licensed under a Creative Commons Attribution 4.0 International License, which permits use, sharing, adaptation, distribution and reproduction in any medium or format, as long as you give appropriate credit to the original author(s) and the source, provide a link to the Creative Commons licence, and indicate if changes were made. The images or other third party material in this article are included in the article's Creative Commons licence, unless indicated otherwise in a credit line to the material. If material is not included in the article's Creative Commons licence and your intended use is not permitted by statutory regulation or exceeds the permitted use, you will need to obtain permission directly from the copyright holder. To view a copy of this licence, visit http://creativecommons.org/licenses/by/4.0/. 


\section{References}

Adler, J. (1987). The Jews of Paris and the final solution: Communal responses and internal conflicts, 1940-44. New York: Oxford University Press.

Arendt, H. (1998). The human condition. Chicago: University of Chicago Press.

Association pour l'histoire des chemins de fer en France (AHICF). (2001). Marie-Noëlle Polino, ed. Une entreprise publique dans la guerre la SNCF 1939-1945. Paris, Assemblée Nationale: 21-22 Juin 2000. Presse Universitaires de France (PUF), Paris, France.

Bachelier, CNRS., (1996). La SNCF Sous L'Occupation Allemand 1940-1944. France: AHICF.

BBC News. (2011). Hugo Boss Apology for Nazi Past, BBC News, September 21 .

Bernstein, Catherine. (Producer and Author), \& Larent Douzou (Coauthor). (2019). La SNCF sous l'Occupation [documentary]. France: Zadig Productions

Bilsky, L. (2017). The Holocaust, corporations, and the law: Unfinished business. Michigan: University of Michigan Press.

Boon, M., \& Wubs, B. (2016). Property, control and room for maneuver: Royal Dutch shell and Nazi Germany. Business History, 1933-1945, 1-20.

Bauman, Z. (1989). modernity and the Holocaust. London: Polity.

Broch, L. (2016). Ordinary workers, Vichy and the Holocaust: French railwaymen and the second world war. Cambridge: Cambridge University Press.

Broch, L. (2014). Professionalism in the final solution: French railway workers and the Jewish deportations, 1942-4. Contemporary European History, 23(03), 359-380.

Brown, A. D., \& Jones, M. (2000). Honourable members and dishonourable deeds: Sensemaking, impression management and legitimation in the 'Arms to Iraq Affair'. Human Relations, 53, $655-689$.

Bush, J. A. (2009). The prehistory of corporations and conspiracy in international criminal law: What nuremberg really said. Columbia Law Review, 109, 1094-1262.

Celerse, G. (2016). Sauvons les enfants!. Lille: Les Lumieres De Lille.

Chatterji, A. K., \& Toffel, M. W. (2018). The new ceo activists. Harvard Business Review, 96(1), 78-89.

Clohesy, W. W. (2004). Interrogating human rights: What purpose? Whose duty? Business \& Society Review, 109(1), 43-65.

Collins, D. (2000). The quest to improve the human condition. Journal of Business Ethics, 26, 1-73.

Commission consultative des dommages et réparations. (1947). Monographie TC 1 . Chemins de fer d'intérêt général, data compiled by Georges Ribeill.

Curran, V. G. (2008). Gobalization, legal transnationalization and crimes against humanity: The Lipietz case. American Journal of Comparative Law, 56(2), 363-402.

Note Remise Par M. Dautry Ministre de L'Armement à M. Paul Reynaud Président du Conseil : Destinée au Conseil des Ministres Dur Mercredi 12 Juin 1940, 14 Heures Mais Remise Seulement le Lendemain au Président du Conseil. Revue D'histoire De La Deuxième Guerre Mondiale 1 (3), pp. 56-58.

Erez, M., \& Earley, F. C. (1993). Culture, self-identity and work. New York, New York: Oxford University Press.

L'Etang, J. (1994). Public relations and corporate social responsibility: Some issues arising. Journal of Business Ethics, 13(2), $111-123$

Federman, S. (2017). Genocides studies and corporate social responsibility: The case of the french national railways (SNCF). Genocide Studies and Prevention., 11(2), 13-35.
Federman, S. (2018). The "Ideal Perpetrator" considering the socialconstruction of accountability: A study of the French National Railways (SNCF). Security Dialogue., 49(5), 327-344.

Ferencz, B. B., \& Taylor, T. (2002). Less than slaves: Jewish forced labor and the quest for compensation. Bloomington, IN: Indiana University Press.

Feig, K. (1981). Hitler's death camps: The sanity of madness. New York, NY: Holms \& Meier.

Fontaine, T. (2017). Cheminots Victims de la Répression: 1940-1945 Mémorial. Paris: Perrin/SNCF/Rails de histoire.

Forbes, N. (1930s). Multinational enterprise, 'Corporate Responsibility' and the Nazi Dictatorship: The Case of Unilever and Germany in the 1930s. Contemporary European History, 16(2), 149-167.

Friedman, M. (1970). The social responsibility of business is to increase its profits. New York Magazine, September 13.

Frye, N. (1957). The anatomy of criticism. London: Penguin Books.

Global Justice Now. (2018). Ending corporate impunity: The struggle to bring about a binding UN treaty on transnational corporations and human rights. Briefing Paper.

Greenwald, A. G. (1980). The totalitarian ego: Fabrication and revision of personal history. American Psychologist, 35(7), 603-618.

Gutman, I. (1990). 'Zyklon B', in Encyclopedia of the Holocaust. New York, NY: Macmillan.

Haas, B. (2019). Opinion: European Companies Get Rich in China's 'Open Air Prison The New York Times, August 21.

Hilberg, R. (2003). The destruction of the European Jews. New Haven: Yale University Press. 3

Hilberg, R. (1961). The destruction of Jews Across Europe. Chicago: Quandrangle Books.

Hobsbawm, E. (1983). Introduction: Inventing traditions. In E. Hobsbawm \& T. Ranger (Eds.), The invention of tradition (pp. 1-14). Cambridge: Cambridge University Press.

International Criminal Court. (no date). Victims before the International Criminal Court: A guide for the participation of victims in the proceedings of the ICC. Victim's Booklet.

Isidore, C. (2019). Krispy Kreme Owners Admit to Family History of Nazi Ties. CNN, March 25.

Jaspers, K. (2001). The question of German Guilt (2nd ed.). New York: Fordham University Press.

Jones, J. (1984). Politics of transport in twentieth-century France. Montreal, QC: McGill-Queen's University Press.

Karasz, P. (2019). Dutch Railway Will Pay Millions to Holocaust Survivors. The New York Times, June 27.

Kelly, M. J. (2016). Prosecuting corporations for genocide. New York, NY: Oxford University Press.

Koehn, D. (2013). Why saying "I'm Sorry" Isn't good enough: The ethics of corporate apologies. Business Ethics Quarterly, 23(2), 239-268.

Köster, R and J Schnaus. (2018). Sewing for Hitler? The clothing industry during the 'Third Reich', Business History Special Issue, 1-13.

Lempereur, A., \& Herrington, R. (2016). Responsibility to protect trumps business as usual: How corporate leaders build heroism to face atrocities. In J. Forrer \& C. Seyle (Eds.), The role of business in the responsibility to protect (pp. 67-97). Cambridge: Cambridge University Press.

Lerchbaum, R., \& Nahum, O. (1999). La SNCF ne souciait pas de ce qu'elle transportait. Actualité Juive, 2, 3-31.

Liu, Y., Feng, M., \& MacDonald, C. (2019). A big-data approach to understanding the thematic landscape of the field of business ethics, 1982-2016. Journal of Business Ethics, 160(1), 127-150.

Maclean, M. (1999). Corporate governance in France and the UK: Long-term perspectives on contemporary institutional arrangements. Business History, 41(1), 88-116.

Makkai, T., \& Braithwaite, J. (1994a). The Dialectics of corporate deterrence. Journal of Research in Crime and Delinquency, 31(4), 347-373. 
Makkai, T., \& Braithwaite, J. (1994b). Reintegrative shaming and regulatory compliance. Criminology, 32(3), 361-385.

Margairaz, M. (1998). Companies under public control in France 1900-50. In N. Whiteside \& R. Salais (Eds.), Governance and labour markets in Britain and France (pp. 25-51). London, UK: Routledge.

Marrus, M. (2010). The case of the French Railways and the deportation of Jews in 1944. In D. Bankier \& D. Michman (Eds.), Holocaust and justice: Representation and historiography of the Holocaust in post-war trials (pp. 245-264). New York, NY: Berghahn Books.

Marrus, M. R., \& Paxton, R. O. (1981). Vichy France and the Jews. New York, NY: Basic Books.

Monsieur de Directeur Général with M. le Président Münzer à la HVD, le 29-12-42. 3 January 1943, Box 72 AJ 474. National Archives of Paris

Moore, Sally Falk. (2018) A Life of Learning Sally Falk Moore. Charles Homer Haskins Prize Lecture for 2018. ACLS Occasional Paper No. 75. April 27, 2018, Philadelphia, PA.

Muchlinski, P. (2001). Human rights and multinationals: Is there a problem? International Affairs, 77(1), 31-35.

Neuborne, B. (2012). Transnational Holocaust-Related Litigation in the United States Courts: The Swiss Bank and German Slave Labor Cases. Presented at the Preparatory Workshop on Transnational Holocaust Litigation. Tel Aviv University, June 22, 2012.

Niezen, R. (2020). \#HumanRights. Palo Alto, CA: Stanford University Press.

Nora, P. (1989). Between memory and history: Les Lieux de Mémoire. Representations, 26, 7-24.

Olson, L. (2017). Last hope island: Britain, occupied europe, and the brotherhood that helped turn the tide of war. New York: Random House Publishing Group.

Pruzan, P. (2001). The question of organizational consciousness: can organizations have values, virtues and visions? Journal of Business Ethics, 29, 271-284.

Remy, J. (1998). Frenchman suing France over Holocaust deportation. London: Reuters.

Richardot, J.-P. (2012). SNCF: héros et salauds pendant l'Occupation. Paris: Broché.

Ribeill, G. (2008). Dossier SNCF et Déportations. Historail, 4, 34-87.

Robinson, S. (2009). The nature of responsibility in a professional setting. Journal of Business Ethics, 88(1), 11-19.

Rosenbloom, Al, \& Althaus, R. A. (2010). Degussa AG and its holocaust legacy. Journal of Business Ethics, 92(2), 183-194.
Sang-Hun, C, and R Gladstone. (2018). How a World War II-Era Reparations Case is Roiling Asia. The New York Times, October 30.

Schaechter, KW. (1999). In a letter sent September 9, 1999 to the Procurer of the French Republic in Paris. Found in the Hoover Institute Archives.

Sethi, S. P. (2015). United Nations' endeavors to protect and enhance human rights around the world. A reflective essay and review of Eric A. Posner, the twilight of human rights law. Journal of Business Ethics, 131(2), 505-507.

Singer, A. E. (2007). Integrating ethics with strategy: Selected Papers of Alan E. World Scientific, NJ: Singer.

Skinner, G. (2008). Nuremberg's legacy continues: The nuremberg trials' influence on human rights litigation in U.S. Courts Under the Alien Tort Statute. Albany Law Review, 71(49), 321-367.

Sluzki, C. E., Ransom, D. C., \& Bateson, G. (1976). Double bind: The foundation of communicational approach to the family. New York, NY: Psychological Corp.

Sohr, N. (2011). SNCF execs pressed for answers. The Daily Record, March 3.

Teitel, R. G. (2003). Transitional justice genealogy. Harvard Human Rights Journal, 16, 69.

UNHRC (United Nations Human Rights Council). (2019). "The Economic Interests of the Myanmar Military; Independent International Fact-Finding Mission on Myanmar.” Forty-second session, 9-27 September.

Verheyde, P. (1999). Les Mauvais Comptes de Vichy: L'aryanisation des entreprise juives. Paris: Perrin.

Volkan, V. (2006). Large group psychodynamics and mass violence. Ciéncia \& Saúde Coletiva, 11(2), 303-314.

Vulpes, J. (1948). La Guerre du Rail. Collection "Patrie," France.

Walker, M. U. (2006). Moral repair: Reconstructing moral relations after wrongdoing. Cambridge: Cambridge University Press.

Wendt, D., \& du Ministre Des Communications du Reich to Monsieur Ministre et Secretaire d'Etat à la Production Industrielle \& aux Communications. (1943). 15 March, Box 72 AJ 419. France: National Archives of Paris.

Wieviorka, A. (2007). La SNCF, la Shoah et le Juge. L'Histoire, 316, 89-99.

Publisher's Note Springer Nature remains neutral with regard to jurisdictional claims in published maps and institutional affiliations. 